\title{
10 The making and circulation of corporate quotas
}

\author{
Mari Teigen
}

\section{Introduction}

The Nordic countries are widely known for their gender-equality achievements. Most famous are their welfare-state policies fostering work-family balance through extensive parental leave and public childcare schemes (Esping-Andersen, 2009; Walby, 2009; Leira, 2012). However, the Nordic countries have also introduced other gender-equality policy innovations such as low-threshold monitoring of equality legislation during the 1970s, gender mainstreaming of public policies during the 1980s, bans on the purchase of sex during the 1990s, and gender quotas for corporate boards, or corporate quotas, during the 2000s (Skjeie et al., 2017). Gender-equality policies typically have traveled across the Nordic countries and, in combination with gender-equality progress in education, labor-market participation, and political representation, have established what is generally called the Nordic gender-equality model (Bergquist et al., 1999; Teigen and Skjeie, 2017).

This chapter examines what could be considered to be the most recent gender-equality policy innovation: gender quotas for corporate boards. Soon after the Norwegian parliament first adopted such regulations in 2003, corporate quotas attracted considerable international attention. Norway's making of corporate quotas initiated what has been called an 'avalanche' of corporate-quota policies in Europe (Machold et al., 2013). Currently, corporate quotas have been adopted by a number of European countries but only one other Nordic country-Iceland.

An important context for the appearance of corporate quotas on Norway's political agenda is the so-called Scandinavian welfare-state paradox: the stark contrast in the Nordic countries between the general genderequality progress and continued gender differences in career achievements. It has been argued that this gap is due to (too) generous welfare-state arrangements and their supposed impediments to gender-equality progress (Mandel and Semyonov, 2006). Although the contrast between generally positive gender-equality achievements and persistent male dominance in the corporate world may appear to be a paradox particular to the Nordic 
countries, male dominance in top positions is a highly visible sign of gender inequality in any country. This backdrop likely is an important reason why corporate quotas soon became an initiative considered by policy actors in many countries. Moreover, it has been claimed that corporate quotas will have an impact on women's careers and hence their representation in executive management, so-called ripple effects (Teigen, 2015).

The strong debate influenced by Norwegian corporate quotas in a number of European countries illustrates the dynamic that bold reforms adopted first in one country often soon attracts attention and lead to new policies in other countries (Weyland, 2005). Although the Norwegian regulations inspired the circulation of corporate quotas to other countries, straightforward copying of Norwegian regulations has not necessarily resulted. This chapter, therefore, presents an analysis of the circulation of corporate quotas in Europe, investigating where they have been adopted, to what extent these policies vary, and, finally, how we can understand the wide popularity of such a highly controversial measure.

This chapter begins with a broad description of the main features of Nordic and Norwegian gender-equality policies and then gives a closer description of Norwegian corporate-quota policy. The main section presents an analysis of the making of corporate quotas in Norway, followed by a mapping of the recent travel of corporate quotas and other softer policies to promote gender balance on corporate boards in a number of European countries. The chapter ends with a discussion on how we can understand the circulation of corporate quotas and to what extent the policies that have circulated resemble the corporate-quota regulations that first emerged in Norway. Finally, this chapter addresses the basic question of why corporate quotas have gained such wide attention and circulation in and beyond Europe.

\section{Making and circulation: input from theory}

Advancing gender equality through policy adoption is a central building block in the Nordic model. However, as argued by Stone (2012), policies seldom emerge in a void but often result from ideas traveling across time, space, and countries. In the Nordic region, gender-equality policies have often been adopted and quickly traveled across countries. To some extent, the spread of policies across the Nordic nations has been facilitated by the role of the Nordic Council of Ministers through its role as an official body for intergovernmental cooperation in the Nordic region. The Nordic countries thus often pay a high degree of attention to policy reforms introduced by their neighbors (Teigen and Skjeie, 2017). At the same time, the international academic literature has attended to the Scandinavian welfare-state paradox, claiming that there is a trade-off between gender equality in the labor market, particularly generous welfare-state arrangements, and gender balance in the workplace (Mandel and Semyonov, 2006; Gupta et al., 2008). This research can be understood as a backdrop that has strengthened 
political concern and will to invent policies restoring the image of the Nordic countries as pioneers of gender equality.

The diffusion literature has emphasized the importance of regional learning as a mechanism of diffusion based on the observation that countries tend to imitate the policies of their neighbors (Dobbin et al., 2007). In this chapter, I map the circulation of corporate quotas and softer policies aimed at promoting gender balance in corporate boards and pay particular attention to how the circulation of corporate quotas fits with the Nordic model. Thus, a central question is to what extent a Nordic model is discernible in the circulation of corporate quotas.

A related concern is the importance of the origin or 'source' of a policy because a policy's capacity to travel is generally assumed to be greater when its source is viewed as authoritative (see introductory chapter by Byrkjeflot et al.; Røvik, 2016). Norway, as the source that introduced corporate quotas, has been central in national and international debates leading to the circulation of corporate quotas. Norway's role as a leader in gender equality has been a central element in debates on whether states and even the European Union (EU) should adopt corporate quotas (Lépinard and Rubio-Marin, 2018). However, being the source also leads to scrutiny for negative policy effects. As alleged in Ahern and Dittmar's (2012) much-debated article, corporate quotas have had negative effects on the economic performance of the companies subject to them. Although such studies are part of debates on policy adoption, foreignization processes - situations when the translating actors find it useful to refer to the source of origin to authorize the policy under debate (cf. introductory chapter by Byrkjeflot et al. in this book)tend to occur at a more general level, concerned with Norway's reputation as one of the world's most gender-equal societies.

Another reason possibly important to the circulation of a new policy is the cost of introducing it. In the book The Price of Gender Equality, Van der Vleuten (2009) analyzed the varied success of women's activism in implementing gender-equality policies in the EU and EU nation states. All policy reforms have potential financial consequences, so new policies may threaten the interests, positions, and ideas of some groups more than others (Van der Vleuten, 2009). In EU policy, social politics have remained primarily a national affair as states have been reluctant to accept supranational policymaking. However, gender-equality policies constitute a clear exception partly because gender equality may be perceived connected to highly valuing the principle of equal rights. Still, gender-equality reforms have been strongly contested based on their costs and the threats they pose to the interests of privileged groups. Generally, the least-costly reforms enjoy the most success in the EU. In this context, corporate quotas are generally a low-cost policy, which may have led to their high attention and wide circulation. This policy's costs and benefits, though, have been a central concern in the debate, as mentioned in the widely cited article by Ahern and Dittmar (2012). At the same time, other studies have shown no effects or positive on company performance (Dale-Olsen et al., 2013). 


\section{The Nordic gender-equality policy context}

Nordic gender-equality policies comprise mainly of three pillars: genderequality legislation, family-friendly welfare-state policies, and gender-quota policies (Skjeie et al., 2019). In 1978, Norway passed probably the world's first gender-equality act. ${ }^{1}$ The law was especially innovative in its combination of prohibiting gender-based discrimination and laying out positive duties and action to promote gender equality. Work-family policies in Norway, as in other Nordic countries, are built on the dual-worker/dual-carer family model (Ellingsæter and Leira, 2006; Ellingsæter, 2014). Key to promoting gender equality is the right to job-protected, generously compensated leave for both parents after child birth and publicly subsidized, high-quality childcare (Ellingsæter and Leira, 2006), including a quota for fathers in the parental-leave scheme (Brandth and Kvande, 2013). Norway long had unmet daycare demand, especially for the youngest children, but today, the vast majority of children younger than school age attend kindergarten (Ellingsæter et al., 2016).

The Norwegian gender-equality legislation's explicit provision favoring positive action paved the way for the introduction of preferential treatment and gender-quota policies (Teigen, 2018). The 1981 Gender Equality Act mandated that both genders be represented on public committees, and from 1988, the law required a balance of at least $40 \%$ for each gender on stateappointed commissions. The Municipal Act of 1992 applied the same regulations to municipal commissions. Most political parties also voluntarily adopted gender-parity policies. Since the mid-1970s, five major Norwegian political parties adopted such measures, but the Conservative, Progress, and Green parties have no such regulations. Party quotas entail a zipper system, in which candidates of each gender alternate on election lists, and each gender is represented by at least $40 \%$ of the members of internal party bodies.

\section{Gender quotas for corporate boards in Norway}

For around 25 years, legal regulations of gender quotas in Norway only applied to public commissions, boards, and councils. However, this changed in 2003 when the Norwegian parliament adopted gender quotas for corporate boards, including public limited liability companies (PLCs), intermunicipal companies, and state-owned companies. Corporate quotas were expanded to cooperative companies ${ }^{2}$ and municipal companies in 2008 and 2009, respectively (Teigen, 2018). The numerous but mostly small- and medium-size limited liability companies (LTDs) are not subject to corporate quotas. Expansion of the scope of the legislation to include these companies, especially the largest ones, has been discussed but not taken up in recent political debates.

Regulations of the gender balance on PLCs board are set out in articles 6-11a of the Norwegian PLCs Act. Similar formulations apply to the other 
kinds of companies covered by corporate quotas. The gender-representation rules are applied separately to employee- and shareholder-elected representatives to ensure independent elections. ${ }^{3}$ For state-owned and intermunicipal companies, regulations adopted in 2003 came into effect in 2004. For PLCs, the 2003 regulations were formulated as 'threat' legislation: Had PLCs not voluntarily met the requirements for gender composition by July 2005, the regulations would have gone into effect. Although female representation on PLCs increased from 2003 to 2005, the target of $40 \%$ of women was not reached. Consequently, in December 2005, the government decided to enforce the gender-balance regulations for the boards of start-up PLCs from 2006 and for all PLCs from 2008. The 40\% target was met when the regulations were fully implemented in 2008. The rather tough sanctions attached to the legislation likely contributed to its successful implementation. The Companies Act applies identical sanctions for breaches of any of its rules, with forced dissolution the final step for companies violating the regulations of this Act. The Norwegian Register of Business Enterprises was set to ensure compliance with the gender balance regulation of company boards, as they are to all aspects of company legislation.

The black line in Figure 10.1 shows the change in the proportion of women on PLC boards, covered by corporate quotas, and the grey line illustrates the proportion of women on the boards of LTDs, not covered by corporate quotas. Women's representation on PLC boards leaped quickly after the 'threat' legislation (2003-2005) was enforced in 2005 continuing to rise, full implementation from 2008. However, the significant distance between

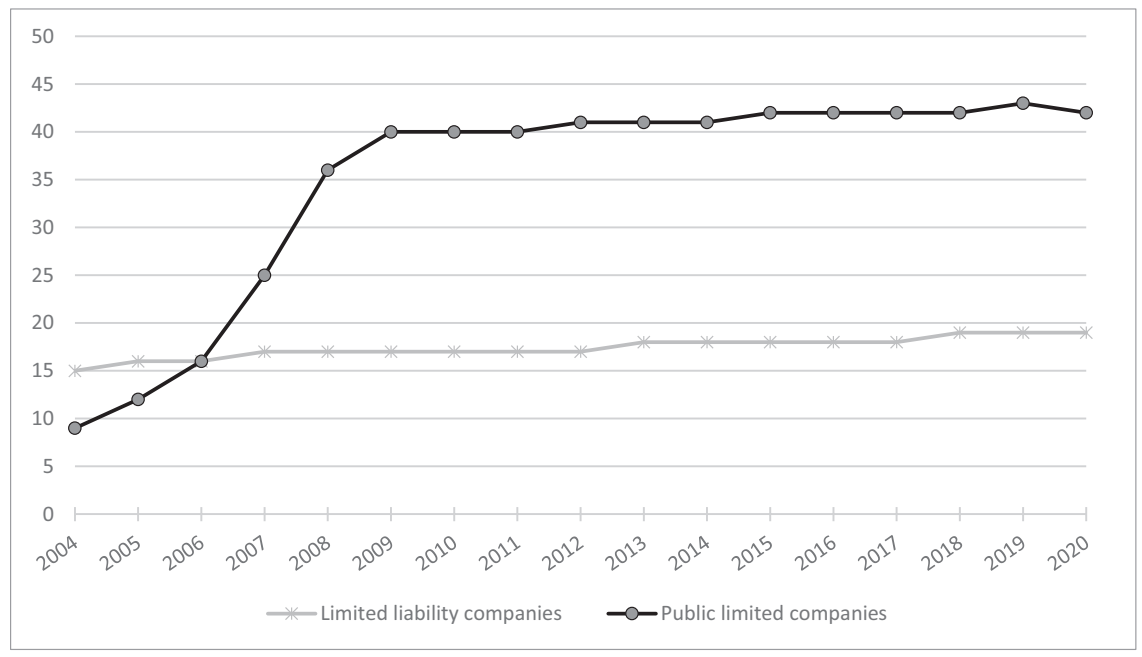

Figure 10.1 Proportion of women on the Boards of Public Limited Companies and Limited Liability Companies, Norway, 2004-2020.

Source: Statistics Norway 
the grey and the black lines indicate that the quota legislation had no ripple effects from PLC boards to LTD boards.

One main reason for the effective implementation of gender quotas for corporate boards obviously was the tough sanctions imposed by the regulations. As shown, the Company Act responds to breaches of all its rules with identical sanctions, beginning with warnings and coercive fines and moving to forced dissolution as the final step. The Norwegian Register of Business Enterprises established to ensure compliance with the company legislation ensure that companies follow the gender-balance rule or comply with it after dialogue with the register. Occasionally, the business register has to enter into dialogues with companies about deviances from a gender-balanced board composition, which has led to correction of the matter.

\section{A brief note on data}

The section on the making of Norway's corporate-board gender-quota regulations is based on the author's earlier studies on the policy's adoption (Teigen, 2015), applying the process tracing method (George and Bennett, 2005). The analysis drew from all the relevant documents from the political process and media debate on the adoption of gender-balance regulations for corporate boards. The most important documents were (1) a consultation proposal on the revision of the Gender Equality Act from the Ministry of Children and Family Affairs in 19994; (2) a white paper from the Ministry of Children and Family Affairs, 'Proposition on Reforms to the Gender Equality Act (2000-2-01) ${ }^{5}$; (3) a consultation proposal on gender representation in PLCs, state-limited companies, and state businesses and a proposal to change the Companies Act and other acts ${ }^{6}$; and (4) a white paper from the Ministry of Children and Family Affairs, 'Proposition on Reforms to Company Legislation on Gender Representation on Company Boards."7 Teigen (2002), Evenrud (2010), Engelstad (2012, 2015), and Sørensen (2011) studied the first stages of the political process in depth. Cvijanovic (2009) analyzed the media debate on the issue of gender quotas for corporate boards.

Studies on the introduction of policies to change the gender composition of corporate boards in several European countries have been a growing field in recent years. However, there is no updated, authoritative, comparative study on the adoption of corporate-quota policies. The mapping presented in this chapter thus was based mainly on several sources: the author's own recent updating on information about the situation in several of the countries, the author's own analysis from 2012 (Teigen, 2012); Seierstad et al. (2017); Hughes et al. (2017); and Piscopo and Muntean (2018).

\section{The making of corporate board gender quotas in Norway}

The corporate-quota regulations were innovative in part because they broke the long-established borders of state intervention in the autonomy of 
economic life. Moreover, they were innovative because the possibility that gender representation on corporate boards could be regulated had not been given much consideration until it suddenly appeared on the political agenda in connection with the revision of the Norwegian Gender Equality Act in 1999. The first record suggesting the legal possibility of gender quotas for corporate boards is found in a letter from the gender-equality ombud on preparing revisions of the Gender Equality Act (Teigen, 2015). Anne Lise Ryel, the gender-equality ombud, and Ingunn Yssen, the director of the Centre for Gender Equality, appear to have played central roles in launching the idea of legally regulating the gender composition of corporate boards (Sørensen, 2011). The revision was initiated and prepared by a minority-center government coalition consisting of the Liberal, Center, and Christian Democratic parties. While reviewing the entire Gender Equality Act, the government proposed expanding the scope of the section requiring that each gender make up at least $40 \%$ of members of publicly appointed boards, councils, and commissions. The proposed revision would include all company boards and the requirement that at least $25 \%$ of members of each gender. ${ }^{8}$ This proposal, however, was withdrawn and not included in the proposed revision of the Gender Equality Act delivered to parliament in 2001. ${ }^{9}$ The proposal met strong opposition, especially from industry and employer organizations (Teigen, 2002). The reason given for withdrawing the proposed regulations of corporate boards was a need for legal clarification.

Gender-balance regulations for corporate boards were presented to parliament in 2003 by a conservative-center government coalition ${ }^{10}$ in 'Proposition to Parliament No. 97 (2002-2003). ${ }^{11}$ Some important changes had been made from the 1999 proposal. First, the 2003 proposal was included in company legislation, not the Gender Equality Act, as in 1999. Second, whereas the 1999 proposition covered all companies regardless of type or size, the new proposal limited gender-composition regulations to state-owned companies, intermunicipal companies, and PLCs. Third, the gender-balance requirement was increased from the original proposal of at least $25 \%$ of each of the genders to at least $40 \%$ of each gender. The new gender-balance rule was passed in parliament with broad political support from all parties except the Progress Party.

The gender-balance regulations carried strict sanctions, and the Norwegian Register of Business Enterprises was set to ensure compliance. The sanction system requires that a company that does not have a legally compliant board be subject to forced dissolution after several warnings, fines, and opportunities for correction. These sanctions follow the normal procedures for contraventions of company legislation but are unusually strong in contrast to the weak sanctions system generally applied to regulations in the Gender Equality Act (cf. Skjeie et al., 2017). ${ }^{12}$

The quota regulations immediately went into effect for state-owned and intermunicipal companies from January 1, 2004. The gender-balance rule for PLCs' boards, though, was formulated with the rather peculiar 'threat' 
provision that if the companies themselves were able to reach a $40 / 60 \%$ gender balance by July 2005, the legislation would not go into effect. Women's representation increased but did not reach the $40 \%$ target by 2005 . Consequently, in December 2005, the government finalized its 2003 decision and enforced the gender-balance rule for newly established companies starting in 2006 and for all PLCs from 2008. The following section lays out the transfer of corporate quotas in Europe.

\section{The persistent travel of corporate quotas}

Norway's adoption of regulations on corporate quotas drew significant international attention. Norwegian politicians and experts traveled the world to discuss the corporate quotas, and the international press wrote extensively on their advantages and disadvantages (Teigen, 2015). In the years following Norway's adoption of corporate quotas, most, if not all, European countries have had heated debates on whether they should adopt such regulations, and quite a few have adopted similar regulations.

Significant variations, though, exist in the corporate-quota policies adopted. Table 10.1 shows the countries that have adopted corporate quotas. These countries diverge in their rules for the minimum and maximum gender distribution. Some have copied the Norwegian 40/60\% principle

Table 10.1 Gender quotas for corporate boards by country, type of quota, year, company type, and sanction

\begin{tabular}{|c|c|c|c|c|c|}
\hline Country & $\underset{\%}{Q u o t a}$ & $\begin{array}{l}\text { Adoption } \\
\text { year }\end{array}$ & $\begin{array}{l}\text { Implementation } \\
\text { year }\end{array}$ & $\begin{array}{l}\text { Company } \\
\text { type }\end{array}$ & Sanctions \\
\hline Norway & 40 & 2003 & 2008 & $\begin{array}{l}\text { All public limited } \\
\text { companies (listed } \\
\text { companies) }\end{array}$ & $\begin{array}{l}\text { Stepwise process: } \\
\text { (1) dialogue and } \\
\text { warning; (2) company } \\
\text { fine; (3) dissolution of } \\
\text { the company }\end{array}$ \\
\hline Spain & 40 & 2007 & 2015 & $\begin{array}{l}\text { All listed companies } \\
\text { and companies } \\
\text { with } 250 \text { or more } \\
\text { employees }\end{array}$ & $\begin{array}{l}\text { Consequences for } \\
\text { state subsidies and } \\
\text { contracts }\end{array}$ \\
\hline Iceland & 40 & 2010 & 2013 & $\begin{array}{l}\text { Companies with } 50 \text { or } \\
\text { more employees }\end{array}$ & No sanctions \\
\hline France & 40 & 2011 & $\begin{array}{l}2014(20 \%) \\
2017(40 \%)\end{array}$ & $\begin{array}{l}\text { Companies with } 500 \\
\text { or more employees } \\
\text { or } € 50 \text { million in } \\
\text { revenue }\end{array}$ & $\begin{array}{l}\text { No payment of fees to } \\
\text { directors }\end{array}$ \\
\hline Belgium & 33 & 2011 & 2017-2018 & $\begin{array}{l}\text { All publicly listed } \\
\text { companies }\end{array}$ & $\begin{array}{l}\text { Empty-seat sanction; } \\
\text { appointments invalid, } \\
\text { and directors' } \\
\text { benefits suspended } \\
\text { until enough women } \\
\text { are appointed }\end{array}$ \\
\hline
\end{tabular}




\begin{tabular}{|c|c|c|c|c|c|}
\hline Country & $\underset{\%}{Q u o t a}$ & $\begin{array}{l}\text { Adoption } \\
\text { year }\end{array}$ & $\begin{array}{l}\text { Implementation } \\
\text { year }\end{array}$ & Company type & Sanctions \\
\hline Italy & $20-33$ & 2011 & $\begin{array}{l}2012(20 \%) \\
2015(33 \%) \\
\quad(\text { expires in } \\
2022)\end{array}$ & $\begin{array}{l}\text { All publicly listed } \\
\text { companies }\end{array}$ & $\begin{array}{l}\text { Stepwise process: (1) } \\
\text { warning; (2) economic } \\
\text { sanctions of the } \\
\text { company; (3) removal } \\
\text { of board members }\end{array}$ \\
\hline Germany & 30 & 2014 & 2016 & $\begin{array}{l}\text { All publicly listed } \\
\text { companies and } \\
\text { companies with } 2000 \\
\text { or more employees; } \\
\text { European } \\
\text { companies (SE) }\end{array}$ & $\begin{array}{l}\text { Empty-seat sanction; } \\
\text { appointments invalid } \\
\text { until enough women } \\
\text { are appointed }\end{array}$ \\
\hline Portugal & 33 & 2017 & $\begin{array}{l}2018(20 \%) \\
2020(33 \%)\end{array}$ & $\begin{array}{l}\text { All publicly listed } \\
\text { companies }\end{array}$ & $\begin{array}{l}\text { Empty-seat and } \\
\text { economic sanctions }\end{array}$ \\
\hline Austria & 30 & 2017 & $2018 / 2022$ & $\begin{array}{l}\text { All publicly listed } \\
\text { companies }\end{array}$ & Empty-seat sanction \\
\hline
\end{tabular}

(Spain, Iceland, and France), while others have more modest requirements (Belgium, Italy, Germany, Portugal, and Austria). The countries also differ in their inclusion criteria. Some regulate gender balance according to which companies are included under the regulations, some according to company type (public limited and traded companies), some according to revenue and number of employees, and some according to all of these factors.

The main differences, though, lie in the sanctions system. The Norwegian Company Act applies identical sanctions for breaches of all rules, from warnings and punitive fines to forced dissolution. It is less clear what sanctions systems other countries have adopted and implemented. According to Gabalon and Gimenez (2017: 58), Spain applies no sanctions, so its corporate quotas are more recommendations. Iceland also does not impose punitive sanctions for non-compliance. France and Belgium have stricter sanctions systems, nullifying appointments and deducting directors' fees until genderbalance targets are reached. The Italian sanctions system gives warnings for non-compliance, followed by economic sanctions on the company and, finally, removal of board members if the target is not fulfilled. The German regulations hold that appointments are not valid until all the seats intended for women board members are filled (Kirsch, 2017: 219). Austria applies an 'empty-seat' sanction, keeping board seats open if not enough women are included. Portugal combines the empty-seat and economic sanctions for non-compliance with quota requirements.

The Danish and Dutch systems have also been characterized as corporate quotas (cf. Piscopo and Muntean, 2018), but the Danish system, in particular, cannot be said to impose quotas. Danish companies, not legislation, set the target thresholds (Table 10.2). The Danish regulations stipulate that companies that do not have a $40 / 60 \%$ gender distribution must set concrete, 
Table 10.2 Gender balance regulation by country, type of requirement, year, company type, and sanction

\begin{tabular}{|c|c|c|c|c|c|}
\hline Country & Quota $\%$ & $\begin{array}{l}\text { Adoption } \\
\text { year }\end{array}$ & $\begin{array}{l}\text { Implementation } \\
\text { year }\end{array}$ & Company type & Sanction \\
\hline Denmark & Set targets & 2012 & 2013 & $\begin{array}{l}\text { Companies with at } \\
\text { least } 156 \text { million } \\
\text { to } 313 \text { million } \\
\text { DKR and } 250 \text { or } \\
\text { more employees }\end{array}$ & $\begin{array}{l}\text { No } \\
\text { sanctions }\end{array}$ \\
\hline Netherlands & 30 & $\begin{array}{l}2013 \text { (expired } \\
2016)\end{array}$ & Immediate & $\begin{array}{l}\text { Balance of at least } \\
€ 17.5 \text { million and } \\
\text { revenue of at } \\
\text { least } € 35 \text { million }\end{array}$ & $\begin{array}{l}\text { No } \\
\text { sanctions }\end{array}$ \\
\hline
\end{tabular}

Table 10.3 Gender balance in corporate governance codes by country, year, and type of recommendation

\begin{tabular}{lll}
\hline Country & Adoption & Recommendation \\
\hline Finland & 2010 & Have at least one female board member \\
Luxembourg & 2013 & Must have representation of both genders \\
Ireland & 2014 & Recommends specific targets depending on board size \\
United Kingdom & 2014 & Recommends specific targets depending on board size \\
Sweden & 2015 & Strive for gender balance on boards \\
\hline
\end{tabular}

realistic, ambitious targets and develop policy to meet them. There is no sanctions system in place for non-fulfillment of companies' targets. Companies are free to set targets they find realistic and ambitious, which do not appear to meet the standards of a quota policy (Agustín et al., 2018). The Dutch system was set to expire in 2016 regardless of the success of the quota regulations. Compliance with the quotas was not enforced with sanctions (Kruisinga and Senden, 2017).

In addition to the spread of corporate-quota regulations, reform of corporate-governance codes stressing the importance of gender-balanced boards has increased sharply. Countries including Finland, Ireland, Luxembourg, Sweden, and the United Kingdom have introduced or strengthened policies to improve the gender balance on corporate boards, mainly through including 'comply-or-explain' recommendations in national corporate social responsibility codes (Table 10.3). These policies differ from rather vague requirements to 'have at least one female board member' (Finland) or 'strive for gender balance on board' (Sweden) (Piscopo and Muntean, 2018).

The EU's own initiative to establish a gender-balance directive for corporate boards has also been part of the ongoing circulation of corporate-quota policies. The European Commission took an active role in the issue and proposed a directive to improve the gender balance among non-executive 
directors of listed companies. The directive was aimed at securing membership of at least $40 \%$ for the underrepresented gender on the boards of through public undertakings by 2018 and all publicly listed companies by 2020. The EU parliament passed the directive, but it did not get support from a majority in the EU Commission (Inderhaug, 2019; Skjeie et al., 2019). ${ }^{13}$

\section{Discussion and conclusion}

The past decade has seen a strong upsurge in the belief that it is possible to politically regulate gender balance on corporate boards and thereby further promote gender balance and gender equality in the business sector. The origin of corporate-quota regulations was Norway, from where corporate-quota policies, as well as softer versions, have circulated to a number of countries in Europe. Policy diffusion studies have been criticized for paying too little attention to what policies diffuse (Røvik, 2016). Indeed, the corporate-quota regulations that have circulated, differ importantly from one another. In this chapter, we have seen that corporate-quota policies have varied in their minimum and maximum standard for gender balance, the company types (registration and size) regulated, and the sanctions imposed for non-compliance.

This final section addresses three questions concerning the circulation of corporate quotas. First, the relevance of a regional learning or neighboring effect (cf. Dobbin et al., 2007) as a mechanism enabling policy diffusion through the circulation of corporate quotas. Second, Norway's importance as a source of the wider spread of corporate quotas. Third, a general understanding of the circulation of such an inherently controversial measure, particularly in light of the 'cost' of introducing it.

Policies to advance gender equality typically have circulated across the Nordic countries and contributed to what has been called a Nordic genderequality model (Teigen and Skjeie, 2017). However, in the Nordic region, the similarities and circulation of gender-equality policies are easier to identify within policies on work-family balance than policies on gender balance in political and economic decision-making (Teigen and Skjeie, 2017). Neither Sweden nor Finland has adopted gender quotas for corporate boards, but Norway and Iceland have adopted quite similar corporate-quota schemes. The Danish scheme is categorized as corporate quotas by some (Piscopo and Muntean, 2017) but seen by others as merely symbolic arrangements with little effects on the gender balance of corporate boards (Agustín et al., 2018). Sweden began a political process parallel to the Norwegian one but has paused that process (Bohman et al., 2012; Heidenreich, 2012; Freidenvall, 2018). In Sweden, the possibility that corporate quotas could be introduced has, to some extent, functioned as a lasting threat in the debate and stimulated taking other actions, which have worked quite successfully. In fact, the rapid growth in women's representation on company boards in Sweden (Freidenvall, 2018: 392), which made gender-quota measures appear to be unnecessarily tough and controversial. In Finland, the question 
of adopting or enlarging the scope of legislation from the boards of stateowned companies to publicly listed companies remain. In both Finland and Sweden, strengthening gender recommendations in corporate-governance codes has been the preferred way to promote gender balance on corporate boards. Generally, the spread of corporate quotas has only moderately, if at all, been facilitated by a neighboring effect, as we cannot identify a Nordic model of corporate-quota policies. A central dynamic identified in the literature on policy diffusion emphasizing the importance of the geographic proximity of neighbor states (cf. Dobbin et al., 2007; Stone, 2012) thus seems to have little relevance to the circulation of corporate quotas.

Another question concerns whether Norway, as the first adopter and the source, may have fueled this international attention. It is believed that corporate quotas may have appeared to be an especially good idea precisely due to Norway's reputation as a leader in advancing gender equality. In a typical dynamic in the early phase of policy diffusion, a policy is introduced by a 'pioneer' state and then adopted by 'laggard' states (cf. Stone, 2012). Norway's successful gender-equality advancements have signaled that policies originating there are what is needed to lead gender equality in the right direction. Norway's 'fast-track' implementation of the requirement for at least $40 \%$ women's representation on corporate boards has contributed to the perception that such regulations can lead to success.

Spain, the second country to adopt corporate quotas, actively used the case of Norway in the reasoning for introducing corporate quotas (see Menendez and Gonzalez, 2012). Corporate quotas were part of a larger package of welfare-state reforms initiated with the change of government in 2004 when the Socialist Party came into power with Jose Luis Rodrigues Zapatero as Prime Minister (Menendez and Gonzalez, 2012). In this reform process, the Nordic/Scandinavian social-democratic welfare-state regime constituted a model for inspiration and an argument for gender equality. The Zapatero government's later ill faith in the reforms and gender-equality policies, however, contributed to delegitimizing the introduced policies (Gabalon and Gimenez, 2017).

Norway also played the role of a leading example in the case of Iceland. Its less-developed gender-equality policies compared to other Nordic countries played an important role in the restructuring of Icelandic politics and economy after the country was heavily hit by the financial crisis in 2009 (Teigen and Skjeie, 2017). Arguments for the importance of introducing corporate quotas referred to the financial collapse and the need to include more women in economic decision-making in order to counteract future economic problems (Styrkarsdottir et al., 2010). In the wake of Iceland's economic collapse, it was argued that the financial crisis was partly due to male dominance (the old-boys' network) and nepotism in economic and political decision-making (Styrkarsdottir et al., 2010). Such criticism seems to have paved the way for copying elements of other Nordic nations' gender-equality policies, the particularly adoption of a corporate-board-quota law. 
Although the adoption of corporate quotas in Iceland appears to have been a response to the crisis, Spain did so before the financial crisis. Indeed, in the case of Spain, the delegitimization of the welfare-state reforms and corporate quotas may have been driven by the same financial crisis, which made it more difficult to argue for such reforms in a time of crisis. That said, the further circulation of corporate quotas in the aftermath of the financial crisis probably indicates that the economic crisis overall contributed to shedding a critical light on the main actors of corporate power, thereby paving the way for corporate quotas.

The final and main question in this chapter concerns why a homegrown, inherently controversial policy such as the corporate-quota policy has been widely and rapidly diffused to a number of countries. Norway's role as a pioneer in gender equality probably has been important, as argued. Policymakers' decisions are often based on limited information, and there is a general lack of certainty about which policies work and which do not. Taking inspiration from policies that seem to work for other countries, especially those recognized as successful in the matter at hand, therefore, appears attractive to many (cf. Dobbin et al., 2007). In addition, the view of corporate quotas as quite spectacular and innovative in breaking the borders of noninterference in businesses' property rights and autonomy probably contributed to the international attention to corporate quotas. News of the policy spread through many significant newspapers and international news- and business magazines and was disseminated by organizations such as the European Women's Lobby and key actors, such as Vivian Reding, vice president of the European Commission (2000-2014).

Finally, corporate quotas are largely costless as they simply require companies to recruit board members of both genders while promising a quick fix to the persistent male dominance of the corporate world. Significant fascination with corporate quotas may derive from such pecuniary circumstances. Policies without consequences for public budgets generally appear attractive to politicians. Admittedly, a counter-discourse, in part, claims that having more women (read: less competent and experienced board members) negatively affects firm performance (c.f. Ahern and Dittmar, 2012). This argument, however, has been met by fierce resistance, arguing that having more women better utilizes the talent pool and is good for business. Corporate quotas thus offer a sharp contrast to other Nordic gender-equality policies, such as parental-leave schemes and state-subsidized childcare, which have heavy fiscal consequences - at least initially and in a narrow fiscal sense.

\section{Notes}

1 The Act Relating to Gender Equality, Ministry of Children and Equality, April 20, 2007, available at https://www.regjeringen.no/en/dokumenter/the-actrelating-to-gender-equality-the-/id454568/ [accessed December 4, 2020]

2 Applying to cooperative companies comprising more than 1,000 members. 
3 The following rules were formulated: (1) When there are two or three board members, both genders should be represented. (2) When there are four or five board members, both genders should be represented by at least two members. (3) When there are six to eight board members, both genders should be represented by at least three members. (4) When there are nine or more board members, each gender should make up at least $40 \%$ of the members. (5) Rules (1)-(4) also apply to the election of deputy members (Authors translation).

4 Consultation Proposal from the Ministry of Children and Family Affairs, 1999. (Høring: Forslag til endringer i likestillingsloven, Barne og familiedepartementet, 1999).

5 Proposition to Parliament 77 (2000-2001), Ministry of Children and Family Affairs. (Ot. prp. 77 (2000-2001)), available at http://www.regjeringen.no/nb/ $\mathrm{dep} / \mathrm{bld} / \mathrm{dok} / \mathrm{regpubl} / \mathrm{otprp} / 20002001 /$ otprp-nr-77-2000-2001-.html?id=123306 [accessed December 4, 2020]

6 Consultation Proposal from the Ministry of Children and Family Affairs, 2001. (Høring: Kjønnsrepresentasjon i styret i allmennaksjeselskaper, statsaksjeselskaper og statsforetak, m.v.-forslag til endringer i allmennaksjeloven og i enkelte andre lover, Barne-og familiedepartementet, 2001), available at http://www. regjeringen.no/en/dokumentarkiv/Regjeringen-Stoltenberg-I/bfd/Horinger/ 2001/Horing-kjonnsrepresentasjon-i-styrer.html?id=421560 [accessed December 4, 2020]

7 Proposition to Parliament 97 (2002-2003), Ministry of Children and Family Affairs. (Ot. prp. 97 (2002-2003)), available at http://www.regjeringen.no/en/ dep/bld/dok/regpubl/otprp/20022003/otprp-nr-97-2002-2003-.html?id=127203 [accessed December 4, 2020]

8 Consultation Proposal from the Ministry of Children and Family Affairs, 1999 (Høring: Forslag til endringer i likestillingsloven, Barne og familiedepartementet, 1999).

9 Proposition to Parliament 77 (2000-2001), Ministry of Children and Family Affairs. (Ot. prp. 77 (2000-2001), available at https://www.regjeringen.no/no/ dokumenter/otprp-nr-77-2000-2001-/id123306/ [accessed December 4, 2020]

10 The conservative-center government coalition comprised of the Conservative, Liberal and Christian Democratic parties.

11 Proposition to parliament 97 (2002-2003), Ministry of Trade and Industry. (Ot. prp. nr 97 (2002-2003)), available at https://www.regjeringen.no/no/dokumenter/ otprp-nr-97-2002-2003-/id127203/ [accessed December 4, 2020]

12 In the consultation, the main argument from employer and industry organizations, in addition to assertions why gender-balance regulations should not be adopted, was that the sanction system was too strict. The government responded that there was no reason to apply other sanctions for this rule. See page 51 in Proposition to Parliament 97 (2002-2003).

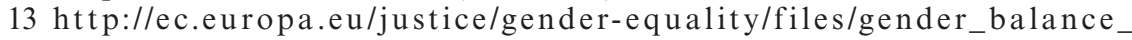
decision_making/131011_women_men_leadership_en.pdf [accessed December 4, 2020]

\section{References}

Agustin, L. R., B. Siim and A. Borchorst (2018), 'Gender Equality without Gender Quotas. Dilemmas in the Danish Approach to Gender Equality and Citizenship', in E. Lépinard and R. R. Marin (eds.), Transforming Gender Citizenship: The Irresistible Rise of Gender Quotas in Europe (Cambridge: Cambridge University Press), 400-423. 
Ahern, K. R. and A. K. Dittmar (2012), 'The Changing of the Boards: The Impact on Firm Valuation on Mandated Female Representation', Quarterly Journal of Economics, 127(1), 137-197.

Bergquist, C. et al. (eds.) (1999), Equal Democracies: Gender and Politics in the Nordic Countries (Oslo: Scandinavian University Press).

Bohman, L., M. Bygren and C. Edling (2012), 'Surge under Threat-The Rapid Increase of Women on Swedish Boards of Directors', in C. Fagan, M. C. Gonzalez Menendez and S. G. Anson (eds.), Women on Corporate Boards and in Top Management. European Trends and Policies (London: Palgrave Macmillan), 91-108.

Brandth, B. and E. Kvande (eds.) (2013), Fedrekvoten og den farsvennlige velferdsstaten [The Fathers' Quota and the Father-Friendly Welfare State] (Oslo: Universitetsforlaget).

Cvijanovic, A. (2009), Rettferdig og rimelig? Om kjønnskvotering $i$ styrene i allmennaksjeselskap (Masteroppgave i politikk og samfunnsendring, Fakultet for samfunnsvitenskap, Høgskolen i Bodø).

Dale-Olsen, H., P. Schøne and M. Verner (2013), 'Diversity among Norwegian Boards of Directors: Does a Quota for Women Improve Firm Performance?', Feminist Economics, 19(4), 110-135.

Dobbin, F., B. Simmons and G. Garrett (2007), 'The Global Diffusion of Public Policies: Social Construction, Coercion, Competition or Learning?' Annual Review of Sociology, 33, 449-472.

Ellingsæter, A. L. (2014), 'Nordic Earner-Career Models-Why Stability and Instability?' Journal of Social Policy, 43(3), 555-574.

Ellingsæter, A. L., R. H. Kitterød and J. Lyngstad (2016), 'Universalising Childcare, Changing Mothers' Attitudes: Policy Feedback in Norway', Journal of Social Policy, 46(1), 149-173.

Ellingsæter, A. L. and A. Leira (2006), 'Epilogue: Scandinavian Policies of Parenthood-A Success Story?', in A. L. Ellingsæter and A. Leira (eds.), Politicising Parenthood in Scandinavia: Gender Relations in Welfare States (Bristol: Polity Press), 265-277.

Engelstad, F. (2012), 'Limits to State Intervention into the Private Sector Economy: Aspects of Property Rights in Social Democratic Societies', in F. Engelstad and M. Teigen (eds.), Firms, Boards and Gender Quotas: Comparative Perspectives (Bingley: Emerald), 235-265.

Engelstad, F. (2015), 'Property Rights, Governance and Power Balances', in F. Engelstad and A. Hagelund (eds.), Cooperation and Conflict the Nordic Way. Work, Welfare and Institutional Change in Scandinavia, available at https://www. degruyter.com/view/title/514448 [accessed December 4, 2020]

Esping-Andersen, G. (2009), The Incomplete Revolution (Cambridge: Polity Press).

Evenrud, M. (2010) Politisk diskurs forut for innføringen av lov om representasjon av begge kjønn i styrene til allmennaksjeselskap (Master diss., University of Oslo).

Freidenvall, L. (2018), 'Gender Equality Without Legislated Quotas in Sweden', in E. Lépinard and R. R. Marin (eds.), Transforming Gender Citizenship: The Irresistible Rise of Gender Quotas in Europe (Cambridge: Cambridge University Press), 366-399.

Gabaldon, P. and D. Gimenez (2017), 'Gender Diversity on Boards in Spain: A Non-mandatory Quota', in C. Seierstad, P. Gabaldon and H. Mensi-Klarbach (eds.), Gender Diversity in the Boardroom: Multiple Approaches beyond Quotas, 
Volume 1: The Use of Different Quota Regulations (London: Palgrave Macmillan), 47-74, available at https://www.palgrave.com/gp/book/9783319561417 [accessed December 4, 2020]

George, A. L. and A. Bennett (2005), Case Studies and Theory Development in the Social Sciences (Cambridge, MA: MIT Press).

Gupta, N. D., N. Smith and M. Verner (2008), 'The Impact of Nordic Countries' Family Friendly Policies on Employment Wages, and Children', Review of Economics of the Household, 6(1), 65-89.

Heidenreich, V. (2012), 'Why Gender Quotas in Company Boards in Norway-And Not in Sweden?', in F. Engelstad and M. Teigen (eds.), Comparative Social Research (Bingley: Emerald), 147-183.

Hughes, M. M., P. Paxton and M. L. Krook (2017), 'Gender Quotas for Legislatures and Corporate Boards', Annual Review of Sociology, 43, 331-352.

Inderhaug, E. (2019), 'En norsk likestillingsreform i EU', in C. Holst, H. Skjeie and M. Teigen (eds.), Europeisering av nordisk likestillingspolitikk (Oslo: Gyldendal Akademisk), 194-213.

Kirsch, A. (2017), 'Women's Access to Boards in Germany-Regulations and Symbolic Change', in C. Seierstad, P. Gabaldon and H. Mensi-Klarbach (eds.), Gender Diversity in the Boardroom: Multiple Approaches beyond Quotas, Volume 1: The Use of Different Quota Regulations (London: Palgrave Macmillan), 205-232, available at https://www.palgrave.com/gp/book/9783319561417 [accessed December 4, 2020]

Kruisinga, S. A. and L. Senden (2017), "Gender Diversity on Corporate Boards in the Netherlands: Waiting on the World to Change", in C. Seierstad, P. Gabaldon and H. Mensi-Klarbach (eds.), Gender Diversity in the Boardroom: Multiple Approaches beyond Quotas, Volume 1: The Use of Different Quota Regulations (London: Palgrave Macmillan), 177-204, available at: https://www.palgrave.com/gp/ book/9783319561417 [accessed December 4, 2020]

Leira, A. (2012), 'Omsorgens institusjoner, omsorgens kjønn', in A. L. Ellingsæter and K. Widerberg (eds.), Velferdsstatens familier — nye sosiologiske perspektiver (Oslo: Gyldendal Akademisk), 78-98.

Lépinard E. and R. R. Marin (2018), 'Introduction: Completing the Unfinished Task? Gender Quotas and the Ongoing Struggle for Women's Empowerment in Europe', in E. Lépinard and R. R. Marin (eds.), Transforming Gender Citizenship: The Irresistible Rise of Gender Quotas in Europe (Cambridge: Cambridge University Press), 1-39.

Machold, S., M. Huse, K. Hansen, and M. Brogi (2013), Getting Women Onto Corporate Boards (Cheltenham: Edward Elgar Publishing).

Mandel, H. and M. Semyonov (2006), 'A Welfare State Paradox: State Interventions and Women's Employment Opportunities in 22 Countries', American Journal of Sociology, 111(6), 1910-1949, DOI: 10.1086/499912.

Menendez, M. C. and L. M. Gonzalez (2012), 'Spain on the Norwegian Pathway: Towards a Gender Balanced Presence of Women on Corporate Boards', in C. Fagan, M. C. Gonzalez Menendez and S. G. Anson (eds.), Women on Corporate Boards and in Top Management. European Trends and Policies (London: Palgrave Macmillan), 169-197.

Piscopo, J. M. and S. C. Muntean (2018), 'Corporate Quotas and Symbolic Politics in Advanced Democracies', Journal of Women, Politics and Policy, 39(3), 285-389. 
Røvik, K. A. (2016), 'Knowledge Transfer as Translation. Review and Elements of an Instrumental Theory', International Journal of Management Reviews, 18, 290-310.

Seierstad, C., P. Gabaldon and H. Mensi-Klarbach (eds.) (2017), Gender Diversity in the Boardroom: Multiple Approaches beyond Quotas, Volume 2 (London: Palgrave Macmillan), available at https://www.palgrave.com/gp/book/9783319561417 [accessed December 4, 2020]

Skjeie, H., C. Holst and M. Teigen (2017), 'Benevolent Contestations: Mainstreaming, Judicialization, and Europeanisation in Norwegian Gender + Equality Debate', in H. McRae and E. Weiner (eds.), Towards Gendering Institutionalism (London: Rowman \& Littlefield International), 121-141.

Skjeie, H., C. Holst and M. Teigen (2019), 'Splendid Isolation? On How a Nonmember Is Affected by - and Affects-EU Gender Equality Policy', in M. Dustin, N. Ferreira and S. Millns (eds.), Gender and Queer Perspectives on Brexit (London: Palgrave Macmillan), 439-461.

Sørensen, S. Ø. (2011), 'Statsfeminismens møte med næringslivet—bakgrunnen og gjennombruddet for kjønnskvotering i bedriftsstyrer som politisk reform', Tidsskrift for kjønnsforskning, 35(2), 102-119.

Stone, D. (2012), 'Transfer and Translation of Policy', Policy Studies, 33(6), 483-499.

Styrkarsdottir, A., R. G. Erlingsdottir and G. L. Rafnsdottir (2010), 'Jämstalldhet och svågerpolitik på island: Ett historisk perspektiv på jämställdhetspolicyn på island', in K. Niskanen and A. Nyberg (eds.), Kön ock makt i Norden. Del II Sammanfattande diskussion och analys, TemaNord 2010 (Copenhagen: Nordisk Ministerråd), 525 .

Teigen, M. (2002), 'Kvotering til styreverv-mellom offentlig og privat handlefrihet', Tidsskrift for samfunnsforskning, 43(1), 73-104.

Teigen, M. (2012), 'Gender Quotas in Corporate Boards - On the Diffusion of a Distinct National Policy Reform', in F. Engelstad and M. Teigen (eds.), Firms, Boards and Gender Quotas: Comparative Perspectives. Comparative Social Research, vol. 29 (Bingley: Emerald, 115-146).

Teigen, M. (2015), 'The Making of Gender Quotas for Corporate Boards in Norway', in F. Engelstad and A. Hagelund (eds.), Cooperation and Conflict the Nordic Way. Work, Welfare and Institutional Change in Scandinavia, available at https:// www.degruyter.com/view/title/514448 [accessed December 4, 2020]

Teigen, M. (2018), 'The 'Natural' Prolongation of the Norwegian Gender Equality Policy Institution', in E. Lépinard and R. R. Marin (eds.), Transforming Gender Citizenship: The Irresistible Rise of Gender Quotas in Europe (Cambridge: Cambridge University Press), 341-365.

Teigen, M. and H. Skjeie (2017), 'The Nordic Gender Equality Model', in O. Knutsen (ed.), The Nordic Models in Political Science. Challenged but Still Viable? (Oslo: Fagbokforlaget), 125-147.

Van der Vleuten, A. (2009), The Price of Gender Equality. Member States and Governance in the European Union (Aldershot: Ashgate).

Walby, S. (2009), Globalisation and Inequalities (London: Sage).

Weyland, K. G. (2005), 'Theories of Policy Diffusion. Lessons from Latin American Pension Reform', World Politics, 25(2), 262-295. 